\title{
INCLUSION OF THE PUBLIC IN THE NATURAL CAPITAL, ECOSYSTEM SERVICES AND GREEN INFRASTRUCTURE ASSESSMENTS (RESULTS OF STRUCTURED INTERVIEWS WITH STAKEHOLDERS OF COMMUNE LIPTOVSKÁ TEPLIČKA)
}

\author{
MILENA MOYZEOVÁ
}

Institute of Landscape Ecology SAS, Štefánikova 3, 81499 Bratislava, Slovak Republic, e-mail: milena.moyzeova@savba.sk

\begin{abstract}
Moyzeová M.: Inclusion of the public in the natural capital, ecosystem services and green infrastructure assessments (results of structured interviews with stakeholders of commune Liptovská Teplička). Ekológia (Bratislava), Vol. 37, No. 1, p. 42-56, 2018.

Nowadays, topics like natural capital assessment, ecosystem services and green infrastructure have become frequent subjects of a number of national and international projects accomplished on local, regional, national and cross-frontier levels. These projects respond to the deterioration of biotopes due to their fragmentation and degradation as a result of constructions and tourism/recreation. This situation requires an economic assessment of ecosystems from the view point of their capacities to satisfy human necessities with simultaneous conservation of the environmental quality, and the optimal status of landscape diversity both in rural and urban areas. The aim of the Green Infrastructure initiative is to stop the loss of land as an irreplaceable natural resource and to contribute to the inclusion of ecological and sustainability aspects into the spatial planning and regional development in rural and urban areas. Green Infrastructure is the tool that may reduce the loss of ecosystem services connected with future occupation of land and improve functions of land. It may support ecological measures aimed at conservation of agricultural landscape and adoption of measures in the sphere of forest and water economies. Important role in the assessment of ecosystems is played not only by the scientists but also by experts and the public at large. This is the reason why ever more stakeholders possessing knowledge of local territory and personal life experience participate in these projects. Their judgments and views, often bearing information important for the above-mentioned assessment, are applied to proposed measures aimed at the improvement of environmental quality and quality of life in terms of sustainability. This article brings the possible example of how to include a selected sample of stakeholders into the assessment of natural capital and ecosystem services on local level in the frame of Green Infrastructure. The aim of this paper is to analyse attitudes of the involved for the evaluation of natural capital and ecosystem services at a local level by means of structured interviews. Obtained views will be applied for the assessment of ecosystem services and proposals aimed at protection and conservation of natural capital and building of green infrastructure. The research was carried out in the model territory of the rural commune Liptovská Teplička.
\end{abstract}

Key words: rural settlements, natural capital, green infrastructure, sociological research, stakeholders. 


\section{Introduction}

Humans are not only part of nature their activities continuously influence components of nature. Effects of human activities on landscape are dual. Human activities connected with nature conservation and rational exploitation of natural, cultural and historical sources are positive, while the ever more expanding and continuous economic growth and prosperity are negative. Disruption, even devastation of landscape, threaten the very human existence as the benefits that nature brings to humans in the form of healthy food, clean air and water and raw materials diminish. It is the reason why solutions and measures bound to mitigate negative effects of human activities on landscape are sought in order to stop the exhaustion of the capacity of ecosystems to fulfil their services indispensable for human life and existence. According to the Resource Efficient Europe plan (COM, 2011a), the deficient protection of natural capital and the underestimation of the value of ecosystem services will have to be tackled by measures supporting intelligent, sustainable and inclusive growth as a priority of the EU in the frame of the document Strategy Europe 2020 (COM, 2010). Investment into green infrastructure is one of the important steps for the protection of natural capital. In the field of biodiversity, the Strategy Europe 2020 (COM, 2011b) is the commitment of the Commission to create the strategy for green infrastructure as a tool providing for ecological, economic, and social benefits by natural solutions. Green infrastructure is based on the principle that conservation and improvement of nature and natural resources should be included into spatial planning and territorial development. Among numerous definitions available, the one by the European Commission (COM, 2013) defines green infrastructure as a strategically planned network of natural and semi-natural areas with varied environmental properties that are created and managed in a way providing a wide scale of ecosystem services. It includes green places (or blue ones in cases of water ecosystems) and additional physical characteristics in dry land (including coastal areas) and the sea areas. Green infrastructure on the mainland is in rural and urban areas.

Natural capital, as defined by OECD (2011) and WB (2012), represents natural resources providing a flow of rare commodities and services. Among the principal components of natural capital are farmland, mineral deposits (crude, gas, coal and minerals), forest, water, fishing areas, and atmosphere. Commodities and services of natural capital are indispensable for economic growth, they provide inputs for agriculture, industry and services, and they increase productivity of agriculture and reliability of services of infrastructure by control of climate. Ecosystem services (services of natural capital) ensue from functions of ecosystems. Ecosystem functions are productive $(\mathrm{P})$ involving production of food, fibres and wood mass, regulative (R), that is, regulation of erosion, sequestration of carbon, and sanitary functions, and cultural, informative, spiritual, and supportive (C). In case these functions (e.g., productive, that is, production of biomass and crops) are financially assessable or if they influence human health (sanitary functions) or economic prosperity, they are referred to as ecosystem services. Regarding the fact that many of these services have still not been financially assessed, they are not sufficiently taken into account by those who prepare economic models (RF, 2010).

Natural and cultural heritage is an integral part of the territorial capital and identity, not only of the EU but also of individual member states, their cities and communes. Excessive use 
of resources is considered a threat to the territorial development. According to the European Commission (COM, 2013), the aim of green infrastructure is to harmonise human activities with natural environment and to boost the possibilities of socio-economic development in local communities when the provision of basic commodities and services must be accompanied by conservation of physical properties of ecosystems and landscape identity. What is the role of the public in this task? Apart from the Aarhus Convention (1998), which talks about the participation of the public in matters concerning the environment, there are also many examples of addressed and accomplished projects. The Institute of Landscape Ecology was involved with the national and international projects such as The Assessment of Ecosystem Services in Historical Structures of Farmland and the OpenNESS Project. According to the European Economic and Social Committee (COM, 2013), inclusion of citizens and organisations into the green infrastructure projects, application of the bottom-up approach and support to partnerships with the representatives of communes, industries, agriculture, forest and water economies, nature conservation, and the NGOs focused on nature conservation and the environment is crucial. This aim, the same as raising of awareness of green infrastructure amongst the main groups of stakeholders was also the one task of our research focused on the ecosystem services and natural capital assessment. The research was conducted in the model territory of rural settlement Liptovská Teplička.

\section{Material and methods}

This assessment of ecosystems and ecosystem services drew on the experience obtained from work on the international project of the EU $7^{\text {th }}$ Framework Programme OpenNESS: Operationalisation of Natural Capital and Ecosystem Services: from Concept to Application. The principal objective of this research was to generate operational frame for the application of the concept natural capital (sum of natural elements and their utility properties for human) and that of ecosystem services (benefits for humans obtained from ecosystems, that is, the live and inanimate nature) in the process of landscape and urban planning, territorial management, and natural resources in the European countries. In the assessment of the natural capital (NC) and ecosystem services (ES), the cascade model (Potschin, Haines-Young, 2013) and the most recent classification of ES by CICES (2013), which discerns three types of ES in landscape: producing $(\mathrm{P})$, regulating $(\mathrm{R})$ and cultural $(\mathrm{C})$ ecosystem services, were applied. Close cooperation of project workers with prominent representatives of relevant public and private institutions and businesses played an important role in this process.

Research aims agreed with those of the European Commission (COM, 2013), that is, improvement of knowledge about ecosystems, estimation of their status, and provision of ecosystem services. Local stakeholders were invited to participate in the assessment. They analysed feasibility and application of NC and ES in the management of the territory with an emphasis on conservation of biodiversity, rational use of natural resources, improvement of water quality, and environmental quality.

The assessment of NC in commune Liptovská Teplička has been carried out by means of structure interviews. Sociological survey was accomplished in 2014 and 2015. Conceptual analysis (Prokša et al., 2008; Chrenščová, 2011) was used for summarization, categorization, and interpretation of viewpoints. The purpose was to find out to what extent the addressed sample of respondents realizes the existence and significance of ecosystem services, natural capital and green infrastructure for the development of the territory from the point of view of their individual professions. Selection of respondents followed the rule that they should represent the basic groups of local stakeholders. They were owners, users, and administrators of plots, local self-administration officials, private farmers, forest managers, water managers, state conservationists, and members of local amateur organisations.

They were asked the following questions:

Which ecosystems are typical for the cadastral territory of Liptovská Teplička? What functions are fulfilled by these ecosystems? What are their benefits for humans and their existence? Did respondents notice any changes, if there were any, and what positive or negative did they bring? 
Administratively, the commune Liptovská Teplička (central part of village - GPS coordinates $48^{\circ} 58^{\prime} \quad 02.6^{\prime \prime}$ $\mathrm{N} 20^{\circ} 05^{\prime} 21.2^{\prime \prime} \mathrm{E}$ ) is part of the administrative Region Prešov, district Poprad (Fig. 1). It is located at 846 to 1429 $\mathrm{m}$ above sea level. The area of its cadastre is $9,845.87$ ha. Share of males and females in its total population of 2,394 (as of 31 December 2016) is 1,174 and 1,220 respectively.

The arable land-meadow-pasture pattern of local landscape is typical for well-developed agriculture and forest economy. Among the land use elements, forest plots with total area of $7,996.61$ ha $(81.22 \%)$ dominate, followed by farmland (1,682.95 ha, $17.09 \%)$, water bodies ( 54.88 ha $0.56 \%$ ), built-up areas (96.12 ha $0.98 \%$ ), and others (15.32 ha $0.16 \%$ ) (Fig. 2). Variegated character of natural conditions along with historical, cultural and socio-economic factors determines a number of ecosystem services.

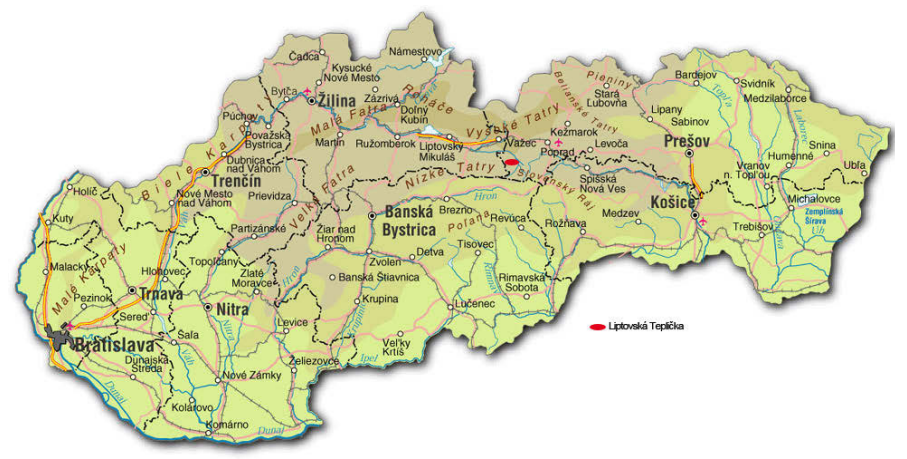

Fig. 1. Localization of Liptovská Teplička village within the Slovak Republic.

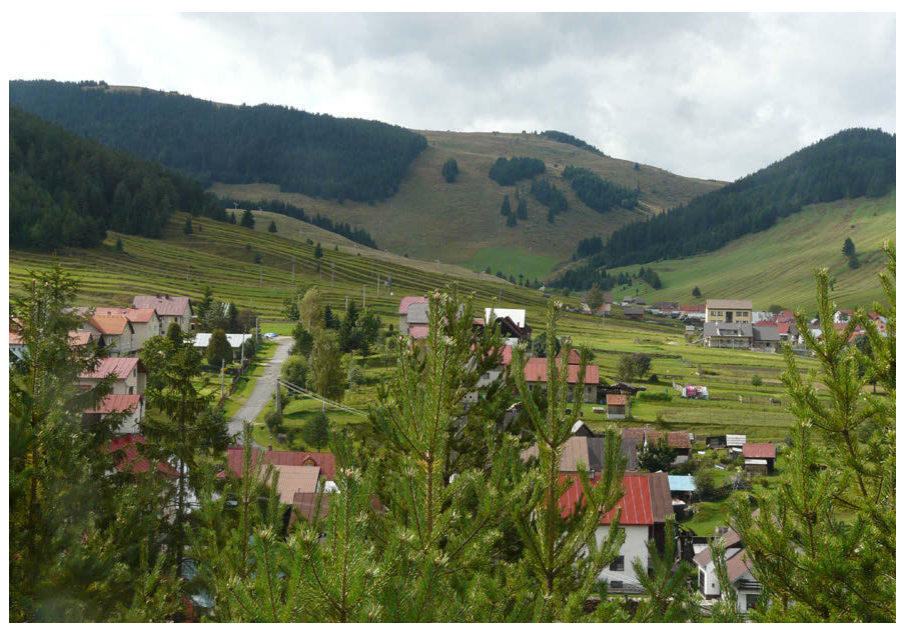

Fig. 2. View of the commune Liptovská Teplička (M. Moyzeová, 2014).

\section{Results}

\section{Agriculture (Shared Agricultural Cooperative members, private farmers)}

Management of farm land or the use of forest greatly influences the status of NC in the cadastral territory of Liptovská Teplička. Tools and measures aimed at supporting of green infrastructure and expansion of areas with high natural value are provided in the frame of the Common Agricultural Policy and the Rural Development Policy (RDP). It concerns the extensive direct support for farmers in the frame of the first CAP pillar in order to prevent land abandonment and fragmentation, and some smaller measures via the RDP programs in the second pillar including unproductive investments, agro-environmental measures (such as conservation of farming landscape, conservation and improvement of hedges, buffer zones, terraces, dry walls, measures in the field of forest and pasturing management, etc.) payments 
encouraging the contact with the Natura2000 network, cooperation in conservation of valuable field edges and conservation and restoration of rural heritage features (COM, 2013). The European Commission included some additional ecologizing aspects in its proposals of the common agricultural policy reform. Apart from other, there is the request that the farmers who accept payments in the frame of the first pillar should conserve the existing permanent grassland and that $7 \%$ of arable land and land containing permanent crops should be the area of ecological interest (COM, 2011c). If correctly applied, these measures may contribute to green infrastructure. How does farming develop in Liptovská Teplička?

Delimited soil types or subtypes and their complexes were classified by their production potential (Vadovičová, Džatko, 1992) to the top producing soils: typical Fluvisol, complex of typical Fluvisol and gleyic Fluvisol. Productive soils: Rendzina-Cambisol, Cambisol-Rendzina and their complexes, typical Cambisol, Rendzina-Cambisol, Rendzina complex Rendzina and Cambisol-Rendzina. Less productive soils: typical Cambisol, Dystric Cambisol, complex typical Cambisol and Dystric Cambisol. Least productive soils: complex typical Cambisol, Dystric Cambisol and Cambisol-Ranker, complex typical Cambisol and Cambisol-Ranker. Granularity of these soils is sand-loamy and loamy (Čurlík, Šály, 2002). In spite of the fact that the farmland here does not belong among the most fertile ones, farming in this territory enjoys a long tradition. Agricultural activities are carried out by the Shared Agricultural Cooperative of Liptovská Teplička and private farmers. Three-field crop rotation is still pursued. Cereals grown here are first of all oats and wheat. Recently, ecological spelt and buckwheat were also introduced.

Analysis of stakeholders' responses showed that:

- Production functions $(P)$ in the cadastral territory of the commune derive from fields, meadows and pastures. Agricultural potential concentrates on sheep and cow keeping and growing of fodder plants. Arable land in this territory is smaller and its productive potential is exploited first of all for production of cereals, legumes, and oil seeds. Ecological husbandry prevails. No artificial fertilizers are used so as to protect waters and soil, and it is the reason why we receive subsidies $(R)$. The Cooperative also dedicates itself to yard sale of assortment of cheese, milk, and meat.

- Tangible assets are the plots around us, that is, fields and pastures used by the sharers. Likewise, mosaics of fields, meadows and pastures with dispersed vegetation represent the natural capital exploited by local husbandmen to grow potatoes.

- The Cooperative respects important landscape elements in the sense of legislation, the Law about nature and landscape protection (No. 543/2002). They are elements located on arable land. The Cooperative work fields located in 'disadvantaged area' are subsidized by the state. But the subsidies are each year lesser. While in 2013 we were eligible to $€ 150 / h a$, this year it was only $€ 120 / h a$. The difference of $€ 30$ per 1 ha is quite an amount that is missing. Apart from fields, mown pastures subsidized by the state also fulfil productive function. They are pastures located around the Cooperative and near the River Čierny Váh. Meadows and pastures with sheep farms are situated in elevated positions. Sheep farms also fulfil other than tangible functions, as they attract tourists (C). 
- In the past, when there was no machinery available, the land was worked by hand with the aid of horses or oxen. The grass was mown by hand (Fig. 3). There were hay-barns in each meadow and each family had as many as five hay-barns. The mowers worked until dark, they passed the night in the hay-barn and the next day, they started at dawn; mowing of a 1-2 ha meadow took 4 to 5 weeks. Five husbandmen owned 8 to 14 ha

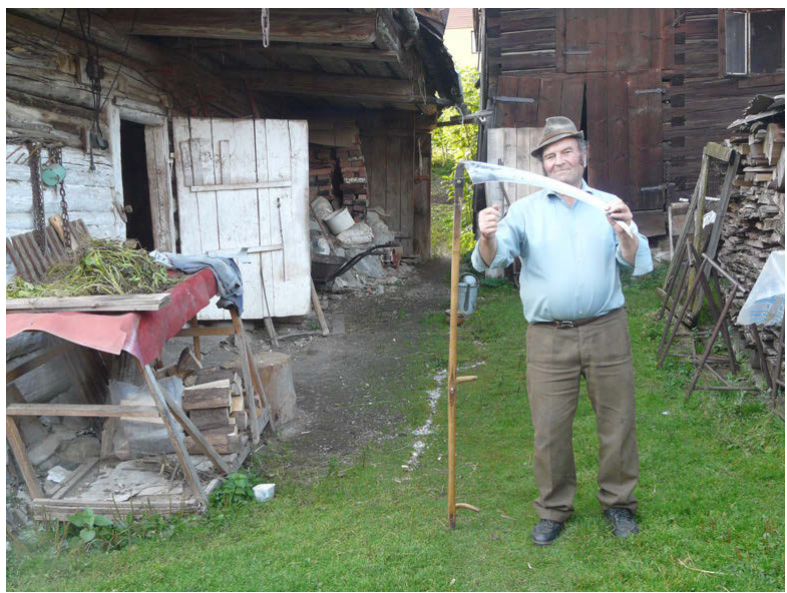

Fig. 3. Local farmers are hand-mowing even today (M. Moyzeová, 2013). of land. Everybody, even the poor farmers, kept at least one cow. Once, this area focused on potato growing and production of milk. There were about 300-400 cows and the surplus milk was passed down to the collection centre $(P)$. The foundation of the Cooperative meant an end to it.

- Farming technology is on an advanced level nowadays. But production is low. Only a quarter of what was grown in 1989 is produced now. It is we ourselves who have destroyed the nature, and now we import products. When the meadows were mowed, we had here abundance of bilberries, raspberries, cranberries and mushrooms too (P). Apart from bilberry fruit, also their leaves were edible, and the tea made of bilberry leaves was rosy and tasty even without adding sugar. Now that the meadows are not mown, and the soil is not worked, everything is gone.

- Great problem now is the shortage of fodder. Wetlands cannot be mown. Everything depends on weather and the number sunny days, so that the hay would dry. It is important to harvest enough fodder for cattle during winter $(P)$.

- $\quad$ Flocks of sheep and cattle were grazing on pastures in the past $(P)$. Nothing is worked today, and the land is overgrown by shrubs and dwarf pine. Once it was maintained by hand mowing, but today it is not maintained and cleaned.

In the eyes of the local farmers, the agricultural production has distinctly dropped in recent years. This critical stance was expressed by several local farmers who work the land in an old-fashioned way, following the local usage and traditions. This method is also favourable from the point of view of biodiversity because it is precisely the terraced fields with balks which maintain the high plant and animal biodiversity. The aim of green infrastructure in the sphere of agriculture is the introduction of thoughtful technologies and procedures and the support of bio-husbandry, which aim at improvement of the associated ecosystem services. The analysis of responses suggests that these aims are met in the farming sector in the 
cadastral territory of Liptovská Teplička. Despite this, the farmers are critical about the drop of production and loss of interest to work the land on the side of younger generation.

Forest economy (forest husbandmen, private farmers)

The objective of green infrastructure in the field of forest economy is to improve conservation of species and biotopes that depend on or are influenced by forest economy. Measures in this area must be then carried out with the aim to reduce fragmentation and degradation of forest in order to maintain their function and capacity to provide the associated ecosystem services.

According to the Environmental Regionalisation of the Slovak Republic (2010), the rate of forestation in the cadastre of Liptovská Teplička is high (45.01 to 60\%, map of forestation by districts). Forest land of this territory is managed by the forest economic unit of Liptovská Teplička and the overall area of forest plots is 5,086.66 ha. The most abundant wood species are spruce and fir trees. Categories of protecting forests and those of forest with special assignment are also represented here. The area of stands of the protecting forest is 2,824.81 ha, that is, $57 \%$ of overall area of growths. Special assignment forest grows on an area of 47.45 ha ( $1 \%$ of overall area of growths).

Comments of an employee of forest administration and a local husbandman:

- $\quad$ Forest ecosystems located around the commune fulfil a productive function, i.e., the production of wood providing a good quality spruce, fir, beech, ash and maple wood $(P)$ on the one side, and regulative function (R), as air regulators and purifiers on the other. Protective function (Pr) is fulfilled by forest in localities with greater sloping threatened by landslide. Our activities are managed by the forest economic unit, and in case of damage, we report the level of damage.

- In the past, forest was first of all the place where the locals could gather forest fruit such as mushrooms, bilberries, raspberries and cranberries $(P)$. Intangible functions are fulfilled by the locality Smreciny that attracts tourists $(C)$. From the point of view of development of tourism and the tours offering views of the environment, the most promising ones are those located in the direction of Králova hol'a Mt. (C).

- The State Forest comp. also owned forest and meadows. They mowed them and collected the hay $(P)$.

Forest growths also fulfil important function, that of mitigation of climate change and providing amounts of biological material; they also capture water and reduce the flood risk, and moreover, they reduce the natural hazards in areas prone to landslides, avalanches and flash floods. What changes have been observed by the stakeholders in the cadastre of Liptovská Teplička?

- The greatest changes in our forests took place in the past. There used to exist beautiful forests around the commune. The branch of forest administration in Liptovský Hrádok 
(state owned forest) yearly harvested $100000 \mathrm{~m}^{3}$ of wood (P). The forest also became thinner because of forest aisles. Huge belts of forest were felled in order to allow rejuvenation, but what followed were strong winds and a bark beetle calamity. Clear cutting capped the process. Our forests are owned by the state, associations of owners or private persons. Everything has been devastated and 40 to 50 years old growths is all that is left.

Responses of employees of forest administration show that they are aware of not only the productive function of forests (wood), but also its regulative and protective functions (protection of soil against landslides, regulation of microclimatic conditions, etc.). Cultural service of forest, which includes recreation opportunities and supply of forest fruit and medicinal plants, are also interpreted as useful and important. The agent that threatens the forest ecosystem is bark beetle that has annihilated hectares of forest growths, especially in the area of the Králova hola Mt., a fact very critically perceived and commented by locals. Potential risk of landslides, because of the absence of stabilizing forest growths, increases on steep slopes. This situation has to be borne in mind in terms of ecosystem measures.

Forest ecosystems in cadastre of Liptovská Teplička are important gene fund sources regarding hunting as well. The territory is part of the hunting ground of the deer game belonging to the Polovnicka oblast' Nizke Tatry - Sever II with an area of 2,650 ha and it is cared for by the Hunting Association of Čierny Váh. Game in this territory is kept and the status and condition of animals is yearly assessed (processed data provided by the Hunting Association of Čierny Váh).

\section{Amateur organisations (members of Hunting Association)}

- $\quad$ Population estimate of deer is 33, that of roe buck and boar is 20 and 12 respectively $(P)$. These numbers are crucial for planning of keeping and hunting. Harvesting oscillates around 10 deer, 5 roe bucks and 9 boars. Apart from these, we also have red grouses, western capercaillies, hazel grouses, wolves, lynxes, bears and wild cats in our hunting ground. Pair of lesser spotted eagle, which occasionally visits the territory, is considered rare. Our main obligation, apart from care for the game, is to maintain the cadastral territory clean.

Analysis of responses of interviewed members of hunting association suggests that hunters are first of all aware of production aspects and functions regarding the numbers of game that live in the territory. Care for the game and regulation of numbers also influence biodiversity in this territory.

\section{Local authority (mayor, workers of the municipal corporation)}

The origins of the commune Liptovská Teplička are associated with colonisation of Gorals who came here from the region of upper Orava. The commune was first mentioned around 1634, when it was owned by the estate of Liptovský Hrádok. People lived off farming, sheep keeping, forest works, logging and tanning. The commune is an important ethnic locality (Encyclopedia of towns and villages of Slovakia, 2005). Apart from the Roman Catholic Baroque church of 1759, there is the National Cultural Monument registered in the Central 
Inventory of Monuments situated on the edge of the commune. It is a railway engine depot with its adjacent area (potential of cultural services). How do both the mayor and the local self-administration officials perceive the commune and its surroundings in terms of natural capital and ecosystem services?

- Quality of landscape where we focus on conservation of traditional approaches also applying the modern management methods using advanced technologies is important for our village, as our final aim is to promote tourism (C). Local self-administration contributes to the enhancement of the environment yearly by about $€ 2,500$. The money is used for out planting of, for instance, hedges, for earth works, etc. Activation works financed by the state engage the Roma population. Some citizens are given jobs in the area of minor communal services, which is also partially financed by the commune. In this way, which encourages the working habit, we employ about 605 persons.

- The whole landscape around Liptovská Teplička fulfils productive, regulative, cultural and ecological functions. Everything relates to everything else. Tourism as a cultural service though, has been rather declining in the last years. While in the past, more than 100 local families offered accommodation to tourists, today it is only 3.

- Surroundings of the commune offer cultural services (C). Potato cellars and log barns, 500 of them in this territory, are much sought out landscape elements attracting tourists. Today the barns contain exhibitions of photographs of the past way of life of the locals.

- Educational trail running through the surroundings of Liptovská Teplička and the bike route Benkovo - Čierny Váh, through the valley of Čiernovážska dolina $(C)$ is another tourist attraction. In future, we want to restore the narrow-gauge forest railway. Natural conditions as important natural capital offer the opportunity to develop winter sports. Ski lifts and boarding hotels providing board and lodging serve to winter recreation.

The mayor attributes important natural potential to the slopes above the commune with ski lifts not only for the development of winter sports, but also for summer tourism. According to his opinion, cultural functions (services) stem from the history of the commune and cultural monuments both in the commune and in its environs. They attract not only the local visitors but also tourists as they offer cultural, spiritual, and aesthetic experience. Analysis of responses reveals that the mayor and the local self-administration officials encourage development of the territory respecting nature conservation and protection of the noteworthy localities and landmarks in this territory, favourable for the development of eco-tourism. As far as the green infrastructure is concerned, they stress on care for the vegetation and expansion of tourist trails as well as increased quality of life in the village.

Nature and landscape protection (workers of the state nature conservation)

The basis of green infrastructure in cadastre of Liptovská Teplička consists of NATURA2000 network elements of ecological stability and the elements of territorial nature protection pursuant the Law No. 543/2002 about nature and landscape protection in the wordings of later issued provisions (Fig. 4). 
Cadastral territory of commune Liptovská Teplička is situated in the National Park Nízke Tatry and its buffer zone. The cadastre of the village includes, according to the State Inventory of Especially Protected Parts of Nature SR (as of 31.12.2015), one small protected area, that is, Nature Reserve (NR) of Martalúzka, which is protected under the fifth conservation degree. Two localities of NATURA2000, that is, the protected bird area of Nízke Tatry and the Site of Community Importance Královohol'ské Nízke Tatry are also in this territory. At the moment, there is proved occurrence of 174 taxa of protected plants in the NP Nízke Tatry, while 138 are vascular plants, 7 mosses, 9 lichens, and 20 mushroom species. Varied types of biotopes and relief dissection as well as inaccessibility of some parts of the territory of the Nízke Tatry Mts. are the characteristics that

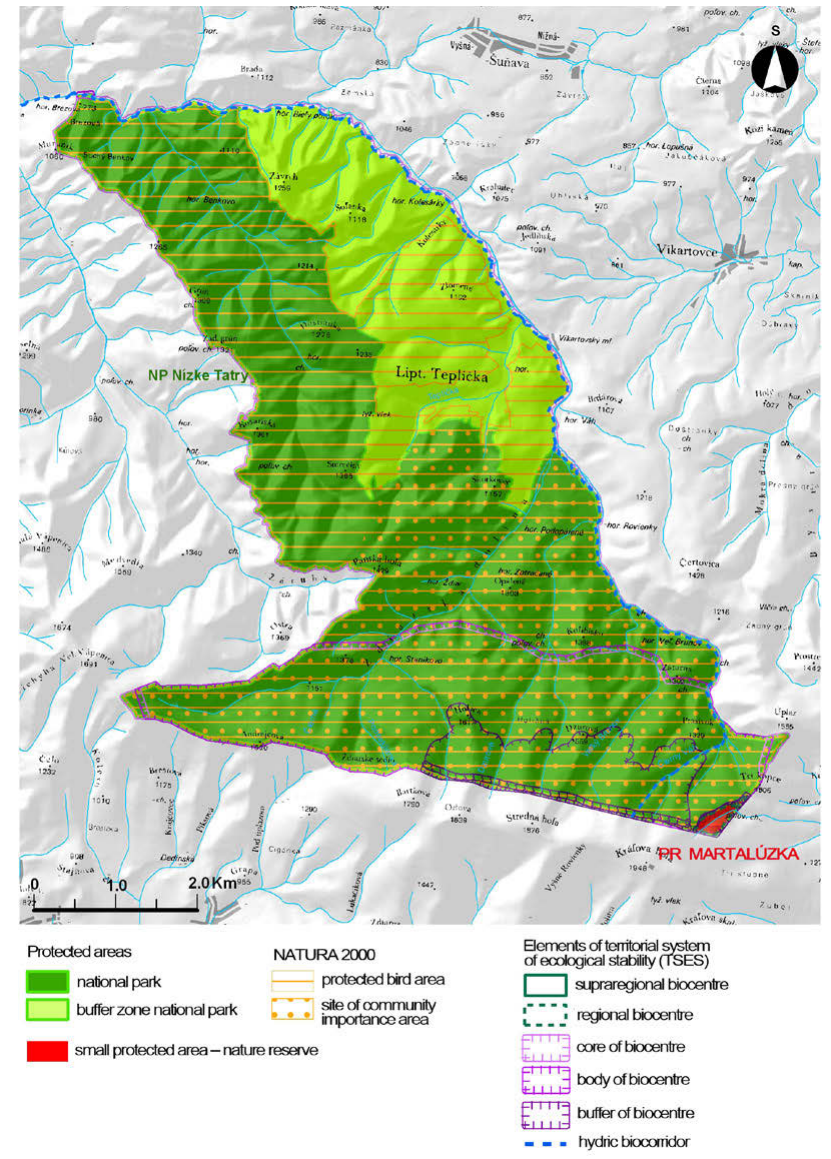

Fig. 4. Elements of nature and landscape conservation. determine the animal species diversity. From the zoo-geographical point of view, this territory is part of the Western Carpathian Province of the Carpathian mountain ranges, where almost the complete West Carpathian, mountain and alpine species live. Many of them are endemic and relic or rare species, such as the rare insects, small but also big mammals, rare beasts and numerous birds (www.napant.sk/druhy/druhy.htm).

The landscape-ecological value of the cadastre is also enhanced by the elements of the territorial system of ecological stability (TSES) and ecologically important landscape segments, and cultural and historical landscape elements. The TSES elements include the Superregional Biocentre Nízke Tatry and the Regional Biocorridor River Čierny Váh. It is a hydric biocorridor stretching along the eastern part of the cadastre boundary, which is a natural migration route of animals in the basin. Ecologically important landscape segments, although they are not protected yet by legislation, require adequate management, conservation and enhancement as 


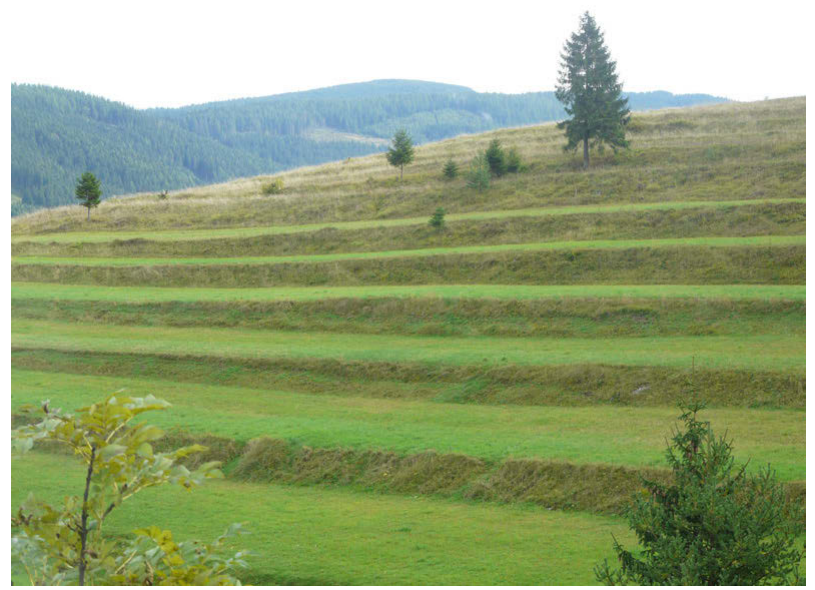

Fig. 5. Terraced fields (M. Moyzeová, 2014).

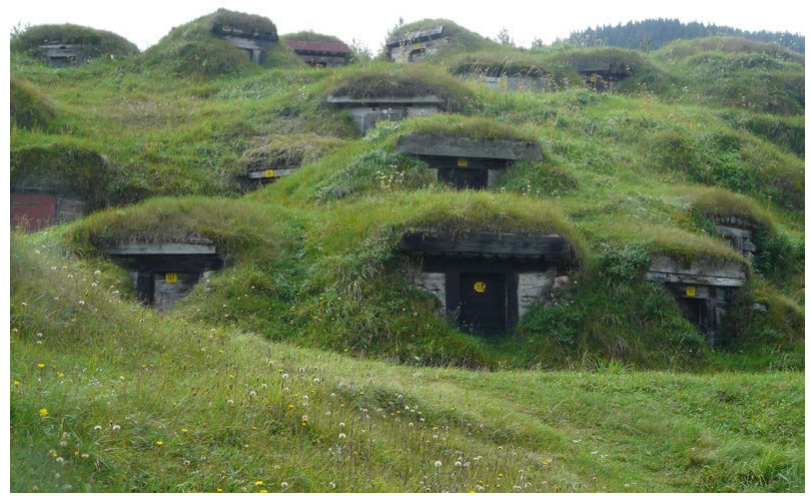

Fig. 6. Potato cellars located on the slope beyond the commune (M. Moyzeová, 2014). future parts of green infrastructure. Typical ecologically important landscape segments are terraces of grassland with tall and shrub vegetation groups (Fig. 5). There are also two wetlands of local significance situated next to the River Čierny Váh and the brook Ždiarsky potok. Both localities fulfil the eco-stabilizing function. They are locally important in terms of hydrology and as hatching sites of amphibians (regulating and supporting services). Cultural/historical landscape elements in the cadastre are the mosaics of small fields and permanent grassland around the built-up part of the inner space of the commune Liptovská Teplička. Potato cellars located on the slope beyond the commune (Fig. 6) and log barns are also part of this historical landscape structure.

Standpoint of state nature protection official to the assessment of natural capital and ecosystem services:

- We do not have any conflicts between nature protection and economically active subjects be-

cause they respect limitations given by legislation. But there are different sentiments concerning husbandry in the village. Conservationists believe that the top productive function in our territory is fulfilled by forests and meadows $(P)$. Meadows, abundant in the cadastre, should be regularly mown for the sake of maintaining productivity and biodiversity. As far as the regulative function is concerned, meadows and the River Čierny Váh are important. The productive function of the stream is only partial because fishing here is restricted. The whole cadastre of the village is important for circulation of nutrients and for intangible functions ensuing from the number of natural, cultural, and historical points of interest (C). 
Analysis of responses of the state nature conservation official reveal that the greatest significance is attributed to forest ecosystems in the cadastre of Liptovská Teplička that are protected in the category of National Park and Nature Reserve. They are reservoirs of biodiversity in this territory. The fact that the conflicts between conservation and land use are not serious and the economic subjects cooperate is positive from the point of view of the green infrastructure initiative.

Water economy (water economist, private farmers)

Green infrastructure helps to maintain good water quality thus fulfilling the guidelines of the Drinking Water Directive (EU) 98/83/ES.

The territory of Liptovská Teplička is remarkable for

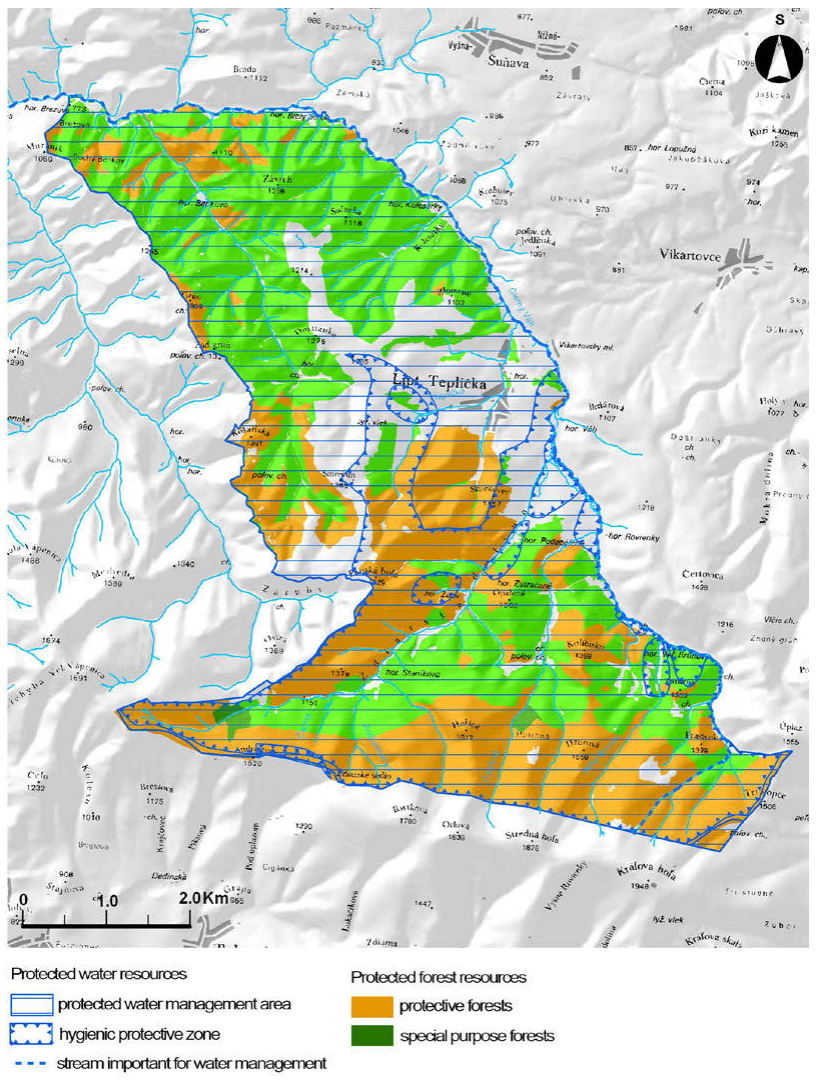

Fig. 7. Elements of natural resources protection. having important natural resources (Fig. 7) including water sources, which are mostly used for supplies. This territory is classified into two main hydrological regions (Malík, Švasta, 2002): Palaeozoic and Mesozoic. It is located in the protected water economy area, that is, Protected Water Area of Nízke Tatry-east. The overall area of the PWA is $805 \mathrm{~km}^{2}$, with water source available for use at a volume of $4.76 \mathrm{~m}^{3} \cdot \mathrm{s}^{-1}$ (www.sazp. sk/slovak/periodika/sprava/psrsk/voda). The edge of the Protected Water Economic Area of upper basin of the River Hnilec extends to the south-eastern tip of the cadastre of Liptovská Teplička. The territory boasts several springs and wells that supply drinking water to the population. Water of these underground sources is of top quality and it satisfies the water quality indicators (Provision No. 496/2010 Ruling of the Government of the SR amending the Ruling of the Government SR No. 354/2006 setting the exigencies concerning water designated for human consumption and quality control of water designated for human consumption); $98 \%$ of the commune's population consume water of the public main (Report on the status of the environment in the Slovak Republic, 2014). The local water main is administered by the Pod- 
tatranská vodárenská spoločnost', a.s water supply company, which supplies water from the above-mentioned water sources in Liptovská Teplička, and from other streams to several towns (Spišská Nová Ves, Kežmarok and Poprad) as well. According to Promulgation of the Ministry of Environment SR No. 211/2005, the river Čierny Váh is an important water economic stream.

Stakeholders evaluated water sources in the following manner:

- Liptovská Teplička had its own water of very good quality, which was also supplied to Poprad, because there was not sic spring in the valley of Spiš $(P)$. There are many bores and springs used for drinking. Among our water sources are springs Velký Brunov and Malý Brunov, Macov and the bore of Rovienky. Water quality is regularly checked.

- We have a well beyond the commune (P). The stream of Teplica once passed through the village. In the 1970s, a water main was constructed. Today the village is supplied from the water main though people living above the village, in the area of ski lifts (Štefanov, Hálky), still have their wells drilled.

\section{Discussion and conclusion}

Many international and Slovak authors are involved in the assessment of potentials. According to the studies of Neef (1966), Graf (1976), Haase (1978), Bierhals (1980), Buchwald (1996), Mazúr, Urbánek (1982), Otahel', Poláčik (1987), Mannsfeld, (1979), Otahel et al. (1991), Otahel' (1994), Drdoš (1990), Izakovičová et al. (1997), Mazúr et al. (1985), and Hrnčiarová (1996), potential is defined as a complex of landscape properties interpreted as an offer, capacity or applicability to provide for various functions with the objective to satisfy society's needs in accordance with harmonious functioning of linkages in the landscape system. Forman and Godron (1986) interpret territorial potential as a possible use of certain area and its values. One of the principal types of territorial potential is the extractable production applying available technologies and expressible by a price. Another principal type of territorial potential difficult to express in economic terms is the basic role of landscape (its components and elements) for regulation, which is pursued with the intention to maintain balance in landscape. The third principal type of territorial potential, that is, the aesthetic, therapeutic and inspirational value of landscape for humans cannot be expressed by or reduced to simple economic terms (Forman, Godron, 1986).

Recently, the term of natural potential has been often replaced by the term natural capital in the context of ecosystem services.

The aim of this paper was to assess the natural capital and ecosystem serviced in cadastral territory of Liptovská Teplička in the view of a selected sample of local stakeholder. It must be also noted that the terms natural capital, ecosystem services and green infrastructure were rather too sophisticated for the addressed respondents. After a brief explanation of these terms, the stakeholders were able to work with them. They assessed the obtained information about ecosystems used in the form of producing, regulating and cultural services based on the thorough knowledge of the territory where they lived and worked. The attitude of the addressed stakeholders active in the field of agriculture, forest economy, water economy, private farming 
and also the representatives of the local self-government to natural resources, nature conservation and preservation of biotopes and biodiversity in their territory is positive. Regarding the provided ecosystem services, the territory of Liptovská Teplička was assessed as a farming landscape with high natural assets and high hygienic requests. As the territory in question is part of the National Park Nízke Tatry and its buffer zone, as well as of the Protected Water Economic Area of Nízke Tatry, several economic activities are limited or restricted by legal protection (Law about nature and landscape protection, Water Law).

The research showed that productive services of the ecosystem were assessed more frequently as they directly influence humans in terms of food, water, wood and fodder.

As all the natural resources represent important natural capital in the territory, it is necessary to preserve and further develop them and to apply the geo-ecosystem approach for the conservation of biodiversity, which is based on a full-area system of protection and optimal land use. Green infrastructure in Liptovská Teplička is based on conservation, maintenance, and protection of natural, semi-natural and artificial ecosystems that supply varied ecosystem services and benefits. In future, it is necessary to encourage the classical farming methods and processing of own harvest, to develop ecological management and production of bio products. These ecological methods applied in the territory increase the species diversity and contribute to increased ecological diversity of the territory. It is also necessary to continue with yard sale. Sheep keeping should be accomplished using the deep litter method in order to protect the soil and water quality against pollution. Green infrastructure in the cadastre of Liptovská Teplička already exists in form of protected territories, the TSES and NATURA2000 elements. Planning and decision-making procedures should respect the occurrence and value of natural capital and to avoid loss of ecosystem services. Stable economic, social and political situation in the commune Liptovská Teplička and drawing on the structural funds will support the traditional farming forms, development of agro-tourism and conservation of biodiversity and landscape diversity.

Acknowledgement

This study is an output of the scientific project No. v 2/0066/15 Green Infrastructure of Slovakia in the frame of Grant Agency of Ministry of Education, Science and Sports of the Slovak Republic and the Slovak Academy of Sciences.

\section{References}

Aarhus Convention (1998). Convention on access to information. Public Participation in Decision-Making and Access to Justice in Environmental Matters.

Bierhals, E. (1980). Ökologische raumgliederung für die landschaftsplanung. In K. Buchwald \& W. Engelhardt (Eds.), Handbuch für planung, gestaltung und schutz der umwelt (pp. 80-104). München: BLV.

Buchwald, K. (1996). Landschaften als gegenstand nutzungs - und umweltbezogener planungen. In K. Buchwald \& E. Engelhardt (Eds.), Umweltschutz - grundlagen und praxis. II. Bewertung und planung im umweltschutz (pp. 1-37). Bonn: Economica Verlag.

CICES (2013). Common International Classification of Ecosystem Services (WWW Document). Biodiversity Information System for Europe. URL http://biodiversity.europa.eu/maes/common-international-classification-of-ecosystem-services-cices-classification-version-4.3 (accessed 11.18.15).

COM (2010). 2020 final, OJ C 88 of 19.3.2011.

COM (2011a). 571 final, OJ C 37 of 10.2.2012.

COM (2011b). 244 final, OJ C 264 of 8.9.2011. 
$\operatorname{COM}(2011 \mathrm{c}) .625 \mathrm{final} / 2$.

COM (2013). 249 final.

Čurlík, J. \& Šály R. (2002). Zrnitost' pôdy. In Atlas krajiny Slovenskej republiky (p. 110-111). Bratislava: MŽP SR, Banská Bystrica: SAŽP.

Drdoš, J. (1990). Contribution to the landscape carrying capacity issue (on example of the Tatra National Park) (in Slovak). Geografický Časopis, 42(1), 3-22.

Encyclopedia of towns and villages of Slovakia (in Slovak) (2005). Lučenec: Vydavatel'stvo PS-LINE.

Environmental regionalisation of the SR (in Slovak) (2010). Bratislava: MŽP SR, Banská Bystrica: SAŽP.

Forman, R.T.T. \& Godron M. (1986). Landscape ecology. New York: Wiley.

Graf, D. (1976). Ökonomische bewertung von naturpotentialen und naturressourcen. Geographische und Ökologische Grundlagen der Landschaftsplanung, Mitteilungsblatt.

Haase, G. (1978). Zur ableitung and kennzeichnung von naturpotentialen. Petermanns Geographische Mitteilungen, $122,113-125$.

Hrnčiarová, T. (1996). Evaluation of the ecological carrying capacity of the landscape. Ekológia (Bratislava), 15(4), 441-447.

Chrenščová, V. (2011). Environmental quality in the perspective of local population in the territory of protected area Horná Orava (in Slovak). Geografický Časopis, 63(1), 69-85.

Izakovičová, Z., Miklós, L. \& Drdoš J. (1997). Landscape-ecological conditions of sustainable development (in Slovak). Bratislava: Veda, vydavatel'stvo SAV.

Landscape atlas of the Slovak Republic (in Slovak) (2002). Bratislava: MŽP SR, Banská Bystrica: SAŽP SR.

Law No. 543/2002 on nature and landscape protection in wording of later issued provisions (in Slovak).

Malík, P. \& Švasta J. (2002). Hlavné hydrogeologické regióny. In Atlas krajiny Slovenskej republiky (p. 104). Bratislava: MŽP SR, Banská Bystrica: SAŽP.

Mannsfeld, K. (1979). Die beurteilung von naturraumpotentialen als aufgabe der angewandten physischen geographie. Materialien zur Raumordnung.

Mazúr, E. \& Urbánek J. (1982). Category of space in geography (in Slovak). Geografický Časopis, 34(3), 309-325.

Mazúr, E., Drdoš, J., Bučko, Š., Huba, M., Otahel, J., Očovský, Š. \& Tarábek K. (1985). Landscape synthesis of the area of Tatranská Lomnica (in Slovak). Bratislava: Veda, vydavatel'stvo SAV.

Neef, E. (1966). Zur frage des gebietswirtschaftlichen potentials. Forschungen und Fortschritte, 40, 65-96.

OECD (2011). Towards green growth. http://www.oecd.org/greengrowth/48224539.pdf

Otahel, J. \& Poláčik Š. (1987). Landscape synthesis of the Liptovská kotlina Basin (in Slovak). Bratislava: Veda, vydavatel'stvo SAV.

Otahel, J., Lehotský, M. \& Ira V. (1991). Environmental planning: Principles and procedures. In Landscape synthesis research. Conference papers. Guelph: University of Guelph.

Otahel, J. (1994). Problems of environmental planning (regional solution) (in Slovak). In Trvalo udržatelný rozvoj a krajinnoekologické plánovanie v európskych horských regiónoch (pp. 167-174). Zvolen: Technická univerzita.

Potschin, M. \& Haines-Young R. (2013). Landscapes, sustainability and the place-based analysis of ecosystem services. Landsc. Ecol., 28, 1053-1065. DOI: 10.1007/s10980-012-9756-x.

Prokša, M., Held, L., Haláková, Z., Tóthová, A., Orolínová, M., Urbanová, A. \& Žoldošová K. (2008). Methodology of pedagogical research and its application to didactics in sciences (in Slovak). Bratislava: PríF UK.

Promulgation No. 211/2005 of the Ministry of Environment SR which ordains the inventory of streams important for water economy and water works (in Slovak).

Provision No. 496/2010 Ruling of the Government of the SR amending the Ruling of the Government SR No. $354 / 2006$ setting the exigencies concerning water designated for human consumption and quality control of water designated for human consumption (in Slovak).

Report on the status of the environment in the Slovak Republic (in Slovak) (2014). Bratislava: MŽP SR.

Republic Frances (2010). National sustainable development strategy 2010-2012 - Towards a green and fair economy. http://www.developpementdurable.gouv.fr/spip.php?page=article\&id_article $=21743$

Vadovičová, E. \& Džatko M. (1992). Assessment of productive soil potential and soil-ecological units of model enterprises (in Slovak). Research study. Bratislava: VÚPÚ.

WB (2012). World Bank. Inclusive green growth: The pathway to sustainable development. Washington: World Bank. https://openknowledge.worldbank.org/handle/10986/6058

www.napant.sk/druhy/druhy.htm

www.sazp.sk/slovak/periodika/sprava/psrsk/voda 